\title{
Development of Vlog Learning Media (Video Tutorial) on Student Materials. Tax at SMK PGRI 1 Jombang
}

\author{
Bics Al Hibra ${ }^{1}$, Luqman Hakim ${ }^{2}$, Tri Sudarwanto ${ }^{3}$
}

\section{ARTICLE INFO}

Article History:

Received 07.01.2019

Received in revised form

25.03.2019

Accepted

Available online 01.10.2019

\begin{abstract}
There needs to be learning media in teaching and learning activities and it is very needed to support learning outcomes and the enthusiasm of learning students and is very helpful for teachers in delivering messages well to students. The purpose of this learning media develo pment research is to find out the feasibility of a Vlog -based learning media or video tutorial validated by some experts both media experts and evaluation experts, the second describes student responses to learning media through the development of Vlog -based learning media, and the third describes student learning outcomes after using Vlog learning media. This study adapted the research method from Thiagarajan which is often referred to as $3 \mathrm{D}$, with the test criteria limited to 16 students with heterogeneous abilities. The results of the research development of vlog learning mediadeclared feasible as a learning media in the tax administration method by experts in terms of the material feasibility aspecte \valuation which consists of objective and subjective questions, media feasibility aspects consisting of quality content and objectives, instructional quality and technical quality, student response and results learn. It can be concluded that the development of V log learning media on the material Tax administration at SMK PGRI 1 Jo mbang is very feasible to use.
\end{abstract}

(C) IJERE. All rights reserved

Keywords:

Material adm, tax instructional media, vlog (video tutorial)

\section{INTRODUCTION}

Learning is essentially a process of interaction with all conditions and environments of students. Learning is also the process of seeing, observing, trying and understanding something from the sender of the message to the recipient of the message. Learning can be done individually, in groups or with the help of others as a guide in learning. Learning activities that generally occur in the school environment are carried out by two or more people, namely teachers and students. Of the two collaborations showing the existence of teacher behavior is learning and student behavior is learning. In this activity there is a link between the materials and learning media needed. The relationship between teachers, students and learning media is dynamic and complex. To achieve a success in teaching and learning activities there are several components that can be developed by the teacher, including: learning objectives, learning strategies, teaching materials, learning media, and learning evaluation.

\section{THEORY AND METHODS}

\section{Supporting Theory}

\section{Cognitive Piaget}

According to Piaget argues that cognitive development is the result of the relationship between brain development and the nervous system with experiences that can help individuals to adapt to their environment. Piaget's developmental theory, representing constructivism, views cognitive development as a process by which children actively build systems and understand reality through their experiences and interactions. Based on Piaget's cognitive development level consists of the sensorimotor stage (0 - 2 years), pre-operational stage (2-7 years), concrete surgery stage (7-11 years), and formal surgery (11 years-adult).

\section{Vygotsky Social Theory}

Vygotsky argued that as Piaget students were able to form knowledge obtained from the results of students' thoughts and activities through language 13. Vygotsky believes that development can be influenced by biological factors that determine elementary functions of memory, attention, perception, and

\footnotetext{
Corresponding e-mail: bics.alhibra94@gmail.com, https://orcid.org/0000-0003-0630-2897

2 Corresponding e-mail: lukmanhakim@unesa.ac.id, https://orcid.org/0000-0002-4662-4113

Corresponding e-mail: trisudarwanto@unesa.ac.id, https://orcid.org/0000-0002-3454-8766

Student of Economics Education, Graduate Program of Surabaya State University ${ }^{1}$

Lecturer of Economics Education, Graduate Program of Surabaya State University ${ }^{2,3}$
} 
Hibra,B.A., Hakim,L. \& Sudarwanto,T. (2019). Development of vlog learning media (video tuto rial) on student materials. Tax at SMK PGRI 1 Jombang. International Journal of Educational Research Review, 4(3),435-438.

stimulus responses, a very important factor is social interaction, meaning social factors can help the development of higher mental functions for concept development, logical reasoning, and decision making.

According to Vygotsky, the learning process will occur if student's complete tasks that have not been studied, but the task is still within the reach of those who are called the zone of proximal development, in the area of development is slightly above the area of one's current development. Higher mental functions generally appear in interpersonal conversations and cooperation 13.

It can be concluded that Vygotsky's theory focuses on the social aspects of learning and interacting socially with others. As well as student learning processes can be updated based on social in the current era that occurs, with the aim of achieving success in the learning process.

\section{Learning Media}

Lesle J. Briggs said that learning media is "media to stimulate students to take place in the learning process". Furthermore, Rossi and Breidle argue that learning media is all tools or materials that can be used for educational purposes, tools including television and radio when used and programmed for educational purposes, then these tools are included in learning media 8. Generally, Garlach found covering media people, materials, equipment and activities that can create an environment where students gain the knowledge, skills and attitudes 8 .

But the media is not just a tool, material, but other things that allow students to get additional or new knowledge.

\section{VLOG (Video Tutorial)}

Media Learning Video is one form of audio visual that is used as a learning medium. Arsyad argues, video is a series of motion pictures accompanied by sound that form a unit which is arranged into a plot, with messages in it to achieve learning in the media tape or disk 3 .

In the opinion of Mardyati (2017), VLOG is another name for Video Blogging which in general or the general public internet users call it $\mathrm{V}$ - Blogging or Vidblogging. Vlog is a form of activity that is made in the form of recording videos or some images that are combined with other sounds, images or animations. Making Vlogs can use devices such as camera phones, digital cameras that are capable of recording video and usually equipped with microphones to carry out Vlog activities.

\section{METHOD}

In the research conducted by Puspasari \& Puspasari (2019), the research and development used was a 4-D model, namely Define, Design, Develop and Disseminate. The results obtained in the study entitled "Development of Student Worksheet Based on Problem Based Learning in Office Management Subjects" gave significant results with data as follows: feasibility percentage was $74.29 \%$, linguistic component was $84 \%$ and response questionnaire was $84 \%$.

Similar to the research conducted by Erfianti, et al (2019) in the "Developing Lup Test Instrument to Measure Higher Order Thinking Skills (HOTS) in Bloomian for Senior High School Students". They also use research with the $4 \mathrm{D}$ development model - Tiagarajan to get the results of developing appropriate instruments to use.

So that the research on developing learning media using VLOG (Video Tutorial) used for learning in the Tax Administration material in class XII Accounting 1 and 2 at SMK PGRI 1 Jombang also uses a development model adapted from Thiagarajan, Sammel, and Sammel, 4-D. Prior to data collection, to obtain a phenomenon researchers conducted pre-research in class XII Accounting 1 and 2. Followed by pretest distribution to find out the results before the development of learning media in the form of Vlogs (Video Tutorials) either from learning outcomes, or student responses. This study was only carried out with 16 students with heterogeneous abilities, consisting of 10 female students and 6 students as a limited trial sample originating from class XII majoring in Accounting $1 \& 2$ at SMK PGRI 1 Jombang. 
Furthermore, several steps were carried out which were adapted from the Thiagarajan $134 \mathrm{D}$ method. To get media validation results, as follows:

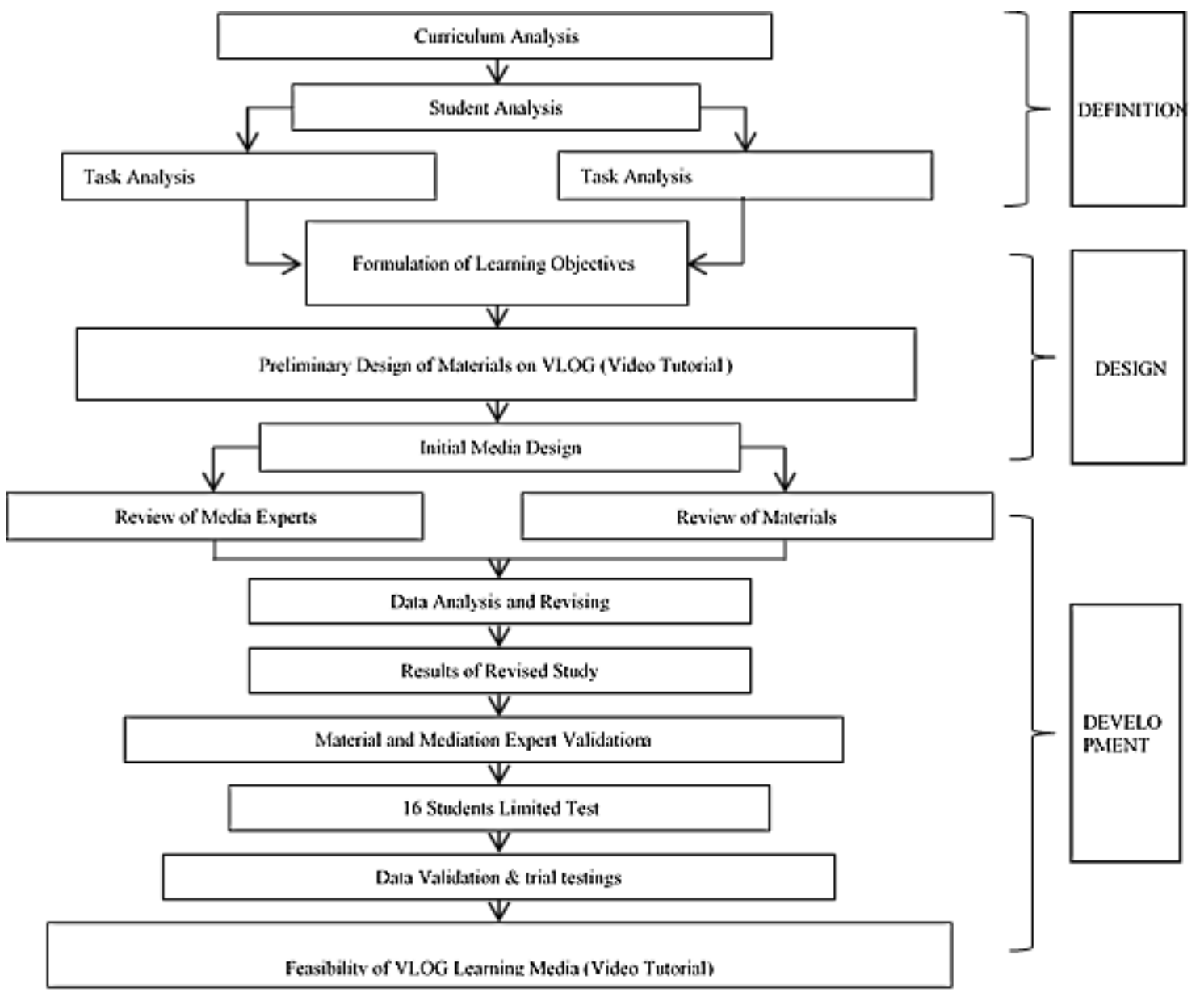

Figure 1.1 4-D Design Phase Scheme in the Development of Vlog Learning Me dia (Video Tutorial) in Student Materials. Tax (Trianto, 2015)

\section{RESULT, DISCUSSION, AND SUGGESTIONS}

The results obtained from the research held in class XII Accounting for Tax Administration material at SMK PGRI 1 Jombang, as follows, will be described according to the results obtained. In terms of the final results or student learning outcomes there are very significant changes. It can be seen from the change in value taken from the pretest that the average value is 79.5 . This value was taken from 16 students as the research sample. Next, the researcher treats students in the delivery of material and the flow of tasks that students must do in this study. Students are given time in completing assignments that are group. At the time time w as spent in making assignments and continued until the VLOG screenings were listened to by all groups. Students in the final stage were given posttest questions to find out the changes in treatment that were carried out this time. And the results obtained are very significant, the change in learning outcomes has increased with an average of 89 , with the same number of students, amounting to 16 people.

From the results of student responses and the results of media and material validation the results were equally significant. As much as $93 \%$ of the results obtained from student responses through questionnaires distributed by researchers that on average the students answered were interested in the learning process by using VLOG learning media (video tutorial) on material that very much needed notes or theories in the form of reading. And as much as $85 \%$ which is declared significant or w orthy of being used as a learning media. This result was obtained from the review process and the validation of media experts. 
Hibra,B.A., Hakim,L. \& Sudarwanto,T. (2019). Development of vlog learning media (video tuto rial) on student materials. Tax at SMK PGRI 1 Jombang. International Journal of Educational Research Review, 4(3),435-438.

To ensure high-quality products, diagrams and letters MUST be made computer or drawn using Indian ink.

Image captions appear below the image, average, and in lower case. When referring to an image in the body of the text, it stands for "Fig." used. Numbers must be numbered in the order displayed in the text.

The table description appears in the middle above the table in upper and lower case. When referring to tables in text, there are no abbreviations used and "Tables" are written in uppercase letters (10).

From the research "the development of VLOG learning media (Video Tutorial) on Tax Administration material at SMK PGRI 1 Jombang" can be concluded that media development research provides very significant results both from learning outcomes, student responses and reviews and validations of experts. The existence of this research, it can be suggested for future research to pay more attention to creativity in the development of learning media in future studies. Because the level of creativity and innovation can increase students' interest and learning outcomes. This research can be followed up as further research as a basis for updating the teachers in innovating in the development of learning media.

How ever, this study also has its drawbacks, the research method has a limitation of the problem that the Thiagarajan 4D method is not entirely used, due to limited costs. This research stopped at the 3D stage or the deployment stage was not carried out. The hope is that further research can develop from all the disadvantages of current research.

\section{REFERENCES}

Arsyad,A.(2000) Media pembelajaran. Jakarta: PT Raja Grafindo Persada.

Erfianti, L.,Istiyono,E. \& Kuswanto,H. (2019). Developing lup instrument test to measure higher order thinking skills (hots) bloomian for senior high school students. International Journal of Educational Research Review. 4(3), 320-329.

Mardyati, Ayu Intan. (2017). Mengenal VLOG [Web log post]. Retrieved from http://ilmuti.org/wpcontent/uploads/2017/02/Mengenal-VLOG.pdf.

Nur. dkk. (1999). Teori pembelajaran kognitif. Surabaya: Unesa Unnipress.

Puspasari, D. \& Puspasari, D. (2019). Development of student w orksheet based on problem based learning in office management subject. International Journal of Educational Research Review. 4(3), 379-385.

Riduwan. (2015). Skala pengukuran variabel - variabel Penelitian. Bandung: Alfabeta.

Rusman, dkk. (2013). Pembelajaran Berbasis Teknologi Informasi dan Komunikasi Mengembangkan Profesional Guru. Jakarta: Rajawali Pers,

Sardiman. Dkk (2011). Interaksi dan motivasi belajar mengajar (Jakarta: PT Raja Grafindo Persada.

Sadiman. dkk. (2010). Media Pendidikan, Pengertian Pengembangan dan Pemanfaatannya. Jakarta: Pustekom Dibud dan PT. Raja Grafindo Persada.

Sanjaya, W. (2008). Perencanaan dan Desain Sistem. Jakarta : Kencana.

Setyosari, P. (2010). Metode Penelitian Pendidikan dan Pengembangan. Edisi Kedua. Jakarta: Kencana

Slameto (2010). Belajar dan Faktor - Faktor yang Mempengaruhinya. Jakarta: Rineka Cipta.

Suprijono, A. (2009). Cooperative Learning: Teori dan Aplikasi PAIKEM. Yogyakarta: Pustaka Pelajar.

Trianto (2015). Mendesain Model Pembelajaran inovatif, Progresif, dan Kontekstual. Jakarta: Kencana. 